UDK: 663/664:005

POSLOVNA EKONOMIJA

BUSINESS ECONOMICS

Godina XIV

Originalni naučni rad

Broj 1

Str $1-19$

doi: 10.5937/poseko17-27043

dr Jelena Tadić ${ }^{1}$, docent

Fakultet poslovne ekonomije,

Univerzitet Educons, Sremska Kamenica - Novi Sad

dr Milan Mihajlović ${ }^{2}$, docent

Fakultet poslovne ekonomije,

Univerzitet Educons, Sremska Kamenica - Novi Sad

\title{
INTEGRATED PERFORMANCE MANAGEMENT MODEL OF A COMPANY USING AN ANALYTICAL HIERARCHY PROCESS
}

\begin{abstract}
The aim of this paper is to test the application of an integrated performance management model on the example of a manufacturing company in the field of food industry in Serbia. The proposed model integrates performance quantification (objective and subjective) on the one hand, and performance improvement, on the other. Objective variables are presented in the form of cost and time dimensions, while analytical hierarchical process (AHP) was used to quantify subjective variables. The research results provide insight into the achieved and optimal performance of the company, which provides a basis for further performance improvements.
\end{abstract}

Key words: Integrated Performance Management Model, Analytical Hierarchy Process, Food industry.

\footnotetext{
1 ajelena83@gmail.com

2 mihamilan@gmail.com
} 


\section{INTRODUCTION}

Managing performance in a changing environment is a very complex and challenging task for a company. Interpretation and action based on information are, to a large extent, difficult if there is no common understanding of how a company should achieve value in accordance with its environment, i.e. if there is no appropriate performance management model. Although the importance of integrated performance management models has been pointed out in the literature, there has been very little research on their design and implementation (Malmi, T., \& Brown, D., 2008). The term integrated is used to qualify an company performance management model. It means a system or model whose components are strategically adjusted and harmonized in order to achieve greater internal consistency of the system. The integrated performance management model combines insight into company control and integrates importance of mission, strategy, critical factors and key performance indicators, integrating quantification and performance improvement. Based on the identified approaches to modeling management flows and company performance, and the proposed integrated model of company performance management, the results of empirical research on the example of a specific company within the food industry of the Republic of Serbia will be presented.

The paper is structured from the following units: the first part gives a brief theoretical background on the performance measurement and improvement system, as well as analytical hierarchical process, the second part presents the research methodology, the third part presents the research results with discussion, while the fifth part presents the conclusion in the form of measures optimizations to improve company performance.

\section{THEORETICAL BACKGROUND}

The contemporary literature on performance management has gradually evolved from providing general recommendations for performance improvement, through formulating a methodology and performance measurement system, to implementing a performance measurement system to improve enterprise performance management. Nevertheless, the topic of quantification / measurement still occupies a central place in the literature. Performance measurement has always been considered the most important tool for performance management, as it provides and integrates all information relevant to performance decision-making. Effective management is based on 
the foundations of efficient quantification/measurement, which results in the functioning of almost all processes in the company.

The performance measurement system has the potential of a very powerful, functional and positive source of power for the company and its employees. When a performance measurement system works well, no management process provides greater functionality than it does, and management focuses on coordinating and rewarding the right things, i.e. the expected results are achieved (Spitzer, 2007). According to Armstrong (2006), performance measurement provides a basis for ensuring and generating feedback, for identifying positive performance that is the basis for building future success, and indicates poor performance so that corrective action can be taken. Performance measurement provides an answer to two fundamental questions: is what is achieved or done worth doing? and was it done well? The performance measurement system can be defined as one of the most interesting managerial innovations in the last few years, due to the fact that it represents an important organizational and informational link between strategic planning and operational control (Tonchia, S., Quagini, L., 2010, p. 35). These authors believe that measuring performance is part of business management, as it allows us to obtain the following information: where we have been, where we are at the moment, where we want to go, how we will know when we arrived (Tonchia, S., Quagini, L., 2010, p. 3). Hall (2008) defines a performance measurement system as a system that translates business strategies into deliverable results, combining financial, strategic, and operational business measures to determine how well a company is meeting its goals. According to the group of authors: "the application of performance information as a feedback control mechanism provides managers with information on effects that do not meet expectations and act as a catalyst for problem identification" (Grafton, J., Lillis, M. A., \& Widener, K. S., 2010, p. 692). All this stimulates problem solving, finding corrective action and organizational learning in the domain of existing activities, and thus focusing managers on achieving current goals.

Analytical hierarchy process (AHP) is a technique, developed by Thomas Saaty $(1980 ; 1994 ; 2003)$ to incorporate several different criteria into the decision-making process. It is applied in decision-making analysis and solving complex problems whose elements are goals, criteria, sub-criteria and alternatives. This method provides a systemic solution for the analysis of multicriteria decision problems characterized by uncertainty. Analytical hierarchical process belongs to the class of methods for soft optimization. It is basically a specific tool for forming and analyzing decision-making hierarchies. AHP first enables the interactive creation of a hierarchy of problems as a preparation of decision scenarios, and then evaluation in pairs of elements of the hierarchy (goals, criteria and alternatives) in the top-down 
direction. At the end, the synthesis of all evaluations is performed and the weight coefficients of all elements of the hierarchy are determined according to a strictly determined mathematical model. The sum of the weight coefficients of the elements at each level of the hierarchy is equal to one, which allows the decision maker to rank all the elements horizontally and vertically. AHP enables an interactive analysis of the sensitivity of the evaluation process to the final ranks of the elements of the hierarchy. In addition, during the evaluation of hierarchy elements, until the end of the procedure and synthesis of results, the consistency of decision makers' reasoning is checked and the correctness of the obtained ranks of alternatives and criteria is determined, as well as their weight values (Saaty, T.L., Vargas, L.G., 2012, p. 3).

\section{RESEARCH METHODOLOGY}

The integrated performance management model contains two phases. The basic idea is, first, to perform performance quantification in order to determine the achieved level of performance, and, if necessary, to set a strategy for performance improvement.

Phase 1. This phase refers to measuring the performance of a company. This includes identification of all variables (key factors, components of factors, and key performance indicators). Identified variables are then classified into objective and subjective categories. Objective factors include the cost and time dimension, which is then classified as effective or ineffective. After obtaining the necessary data based on the questionnaire, quantification of objective variables is performed, while subjective variables are measured using AHP.

Phase 2. This phase refers to improving company performance.

\section{Performance measurement}

\section{Step 1. Identification of variables}

The first step within the performance measurement phase is identification, i.e. selection of all research variables (key factors, factor components and key performance indicators). Key performance indicators represent the basis for the formation of factor components, and factor components are the basis for the formation of key factors. Gomes et al. (2006) identified about 65 key performance indicators that can be grouped into the following groups of factors: efficiency, product quality and consumer satisfaction, product and process innovation, flexibility, human resources management, social responsibility. 
According to the same authors, some of the key performance indicators that can be used are: operating cost per employee, cost of goods sold, production time, production compared to planned production, capacity utilization, number of new products (in the last three years), percentage of patent-protected products, customer complaints, percentage of correct shipments, motivation index, annual investment in training, investment in new technology, product features (Gomes, Yasin \& Lisboa, 2006).

\section{Step 2. Classification of variables into objective and subjective}

Identified variables for the purpose of performance measurement, can be classified into two categories: objective (quantitative) and subjective (qualitative). Objective variables include the cost and time dimension, which are then classified as effective or ineffective (Parthiban, Goh, 2011, p. 268) (Aravindan, Punniyamoorthy, 2002, p. 152)

- Effective cost (EC) - include costs that need to be maximized in order to increase performance (for example: capacity utilization);

- Ineffective cost (IEC) - include costs that need to be reduced in order to increase performance (for example: operating costs per employee);

- Effective time (ET) - all productive time used to increase performance (for example: product development time);

- Ineffective time (IET) - all unproductive time (for example: age of equipment).

Subjective variables represent all those that cannot be represented by a cost and time dimension. For example: quality within the key success factors. Food quality and consumer satisfaction, within the components of the factor, and product characteristics, safety and correctness, price-quality ratio, customer loyalty, response to customer complaints, within the key performance indicators.

Step 3. Preparation of a questionnaire on the proposed variables and conducting research

After classifying the parameters into the second step, it is necessary to prepare a questionnaire in which it is necessary to determine the importance of each criterion based on the comparison of pairs of criteria. The questionnaire consisted of three parts or levels. Within the first level, concrete company from food industry determined the importance of the offered key factors based on a comparison of key factor pairs. In the second level, the importance of the offered factor components was determined, and in the third level, the importance of the offered key performance indicators was examined, based on the comparison of key performance indicator pairs. 
Step 4. Objective variables measurement

After obtaining the necessary data based on the questionnaire, it is possible to quantify the objective variables in the form of cost and time dimension. Objective variables measurement (OVM) is performed using the following analytical expression (Parthiban, Goh, 2011, p. 269):

$$
O V M=C T E_{i} \frac{1}{\sum_{i=1}^{m} C T E_{i}},
$$
efficiency.

$m$ - number of performance observations; CTE - cost - time

Cost - time efficiency (CTE) of the company $i$ is obtained by applying the following analytical expression:

$$
C T E_{i}=E C_{i} \frac{1}{\sum_{i=1}^{m} E C_{i}}+\left[I E C_{i} \frac{1}{\sum_{i=1}^{m} I E C_{i}}\right]^{-1}+E T_{i} \frac{1}{\sum_{i=1}^{m} E T_{i}}+\left[I E T_{i} \frac{1}{\sum_{i=1}^{m} I E T_{i}}\right]^{-1},
$$

$E C_{\mathrm{i}}$ - the effective cost of company $i ; I E C_{\mathrm{i}}-$ the ineffective cost of company $i ; E T_{\mathrm{i}}$ - the effective time of company $i ; I E T_{\mathrm{i}}-$ the ineffective time of company $i$.

Step 5. Subjective variables measurement

For the purpose of subjective variables measurement $(S V M)$, it is necessary to apply the analytical hierarchical process $(A H P)$. A quality solution is achieved by the AHP method by applying four basic steps:

(1) Constructing a hierarchical structure of variables. Methodologically, AHP is a multi-criteria technique based on the decomposition of a complex problem into a hierarchy. The goal is at the top of the hierarchy, while the criteria, sub-criteria and alternatives are at lower levels.

(2) Determining the preference and importance of the criteria. After determining the hierarchical structure of the model, it is necessary to develop a set of matrices in which the relative preferences of each of the alternatives $\left(\mathrm{B}_{\mathrm{i}}\right)$ according to individual criteria $\left(\mathrm{A}_{\mathrm{k}}\right)$ are numerically defined. Then, the relative importance of each of the stated decision-making criteria is determined by mutual comparison. When comparing alternatives and criteria, each pair is assigned a numerical value that expresses the degree of preference of a particular alternative. When comparing a pair of criteria, the question arises as to what is more important or what has a greater impact, thus determining the coefficient of their relative importance. If a large number is assigned when comparing the two criteria, it means a larger difference in the level of the observed criteria. A scale of 1 to 9 is 
most commonly used to determine the degree of preference, as shown in the following table:

Table 1. Saaty's scale of evaluation (Saaty, T.L., Vargas, L.G., 2012, p. 6).

\begin{tabular}{ccc}
\hline $\begin{array}{c}\text { Degree of } \\
\text { preference }\end{array}$ & Definition & Explanation \\
\hline 1 & $\begin{array}{c}\text { Of the same } \\
\text { significance } \\
\text { Weak dominance }\end{array}$ & $\begin{array}{c}\text { The two elements are of identical } \\
\text { importance in relation to the goal } \\
\text { Experience or reasoning slightly } \\
\text { favors one element over another } \\
\text { Experience or judgment significantly } \\
\text { favors one element over another } \\
\text { The dominance of one element } \\
\text { confirmed in practice }\end{array}$ \\
5 & Strong dominance & Demonstrated \\
dominance & Dominance of the highest degree \\
\hline
\end{tabular}

The values found between these categories are used when the decision maker is not entirely sure what degree of preference he would assign to a particular alternative (or criterion). For example, if the decisionmaker considers that one alternative is much more significant than another, but cannot qualify it as much more significant, the degree of preference would be 6 .

(3) Calculation of relative priorities for all alternatives and decision criteria. The previous step results in the formation of a set of evaluation matrices that are further used to calculate relative priorities. As a result of comparing $n$ alternatives, an evaluation matrix $B$ (see figure 1) was obtained according to the criterion $A_{k}$ of dimension $n \times n$ in which each element $b_{i j}$ represents the preference coefficient of alternative $B_{i}$ in relation to alternative $B j$.

\begin{tabular}{c|cccc}
$A_{k}$ & $B_{1}$ & $B_{2}$ & $\cdots$ & $B_{\mathrm{n}}$ \\
\hline$B_{1}$ & $b_{11}$ & $b_{12}$ & $\cdots$ & $b_{\mathrm{n}}$ \\
$B_{2}$ & $b_{21}$ & $b_{22}$ & $\cdots$ & $b_{2 n}$ \\
$\vdots$ & $\vdots$ & $\vdots$ & $\vdots$ & $\vdots$ \\
$B_{n}$ & $b_{\mathrm{n} 1}$ & $b_{\mathrm{n} 2}$ & $\cdots$ & $b_{\mathrm{nn}}$
\end{tabular}

Figure 1. - Evaluation matrix $B$

The reciprocal value of the comparison results is placed in the $b_{j i}$ position in order to preserve the consistency of reasoning. For 
example, if alternative 1 was slightly favored over alternative 2 , the $b_{12}$ matrix would be numbered 3 , and the $b_{21}$ would be a reciprocal, $1 / 3$. For matrix $B$, its maximum eigenvalue, $\lambda_{\max }$, can be determined first, and then the corresponding eigenvalue vector, i.e. the vector of approximate values of weight coefficients, $w_{i}$. The determined vector of weight coefficients is multiplied by the weight coefficient of the higher level element used as a criterion in the comparison. The procedure is repeated going to lower levels of the hierarchy. Weight coefficients are calculated for each element at a given level and they are then used to determine composite relative weight coefficients of elements at lower levels. Finally, the alternative with the highest composite weighting factor is chosen. When the normalized eigenvector is known, the maximum eigenvalue $\left(\lambda_{\max }\right)$ can also be determined, which is calculated using the following analytical expression (Parthiban, Goh, 2011, p. 270):

$$
\lambda_{\max }=\frac{1}{n} \sum_{i=1}^{n} \lambda_{i} .
$$

The maximum value of the eigenvector $\left(\lambda_{\max }\right)$ is further used to test the consistency of the model.

(4) Logical consistency check. Bearing in mind that the number of comparisons is often large $\frac{n(n-1)}{2}$, it happens that matrix $B$ is not completely consistent. If, for example, it is claimed that $A$ is much more important than $B, B$ is slightly more important than $C$, and $C$ is slightly more important than $A$, inconsistency occurs, which reduces the reliability of the results. Errors in reasoning are measured by calculating the consistency index $(\mathrm{CI})$ for the obtained comparison matrix, and then the consistency ratio $(C R)$. The consistency index $(C I)$ is calculated according to the following relation (Parthiban, Goh, 2011, p. 270) (Salem, 2010, p. 96):

$$
C I=\frac{\left(\lambda_{\max }-n\right)}{(n-1)},
$$

where $\lambda_{\max }$ is the maximum eigenvalue of the comparison matrix. The closer $\lambda_{\max }$ is to the number $\mathrm{n}$, the smaller the inconsistency will be. The consistency ratio $(C R)$ is the ratio between consistency index $(C I)$ and the random index (RI) (Parthiban, Goh, 2011, p. 270) (Salem, 2010, p. 96):

$$
C R=\frac{C I}{R I} \text {. }
$$

The random index $(R I)$ depends on the order of the matrix, and is taken from Table 2 in which the first row represents the order of the matrix and the second the random index. 


\begin{tabular}{|c|c|c|c|c|c|c|c|c|c|c|c|c|c|c|c|}
\hline $\begin{array}{l}\text { Order } \\
\text { of } \\
\text { matrix } \\
\text { (n) }\end{array}$ & 1 & 2 & 3 & 4 & 5 & 6 & 7 & 8 & 9 & 10 & 11 & 12 & 13 & 14 & 15 \\
\hline $\begin{array}{l}\text { Rando } \\
\mathrm{m} \text { index } \\
(R I)\end{array}$ & 0 & 0 & $\begin{array}{c}0.5 \\
2\end{array}$ & $\begin{array}{c}0.8 \\
9\end{array}$ & $\begin{array}{c}1.1 \\
1\end{array}$ & $\begin{array}{c}1.2 \\
5\end{array}$ & $\begin{array}{c}1.3 \\
5\end{array}$ & $\begin{array}{c}1.4 \\
0\end{array}$ & $\begin{array}{c}1.4 \\
5\end{array}$ & $\begin{array}{c}1.4 \\
9\end{array}$ & $\begin{array}{c}1.5 \\
1\end{array}$ & $\begin{array}{c}1.4 \\
8\end{array}$ & $\begin{array}{c}1.5 \\
6\end{array}$ & $\begin{array}{c}1.5 \\
7\end{array}$ & $\begin{array}{c}1.5 \\
9\end{array}$ \\
\hline
\end{tabular}

If the consistency ratio $(C R)$ is less than 0.10 ; the result is accurate enough and there is no need for corrections in comparisons and repetition of calculations. If the consistency ratio is greater than 0.10 ; the results should be re-analyzed and the reasons for inconsistencies established, removed by partial repetition of comparisons in pairs. If repeating the procedure in several steps does not lead to a decrease in the consistency ratio, to a tolerance limit of 0.10 ; all results should be discarded and the whole evaluation process repeated.

\section{Step 6. System performance measurement}

Based on the use of data on objective and subjective variables, the performance of the company as a system is determined. The system performance measurement of company $i\left(S P M_{i}\right)$ is performed based on the following analytical expression (Parthiban, Goh, 2011, p. 271) (Aravindan, Punniyamoorthy, 2002, p. 152):

$$
S P M_{i}=\alpha\left(O V M_{i}\right)+(1-\alpha) S V M_{i},
$$

where $\alpha$ reaches a value from zero to one, $\alpha$ - objective variables weight, $(1-\alpha)$ - subjective variables weight.

\section{Performance improvement}

In order to move from a performance measurement to performance management, there must be the ability to use performance measurement results to improve performance. Thus, based on the performed measurement (quantification) of the company's performance, the bases for step 7: performance improvement were created. Thus, the foundations have been created for more relevant, integrated, balanced and performance-oriented performance management (Tangen, 2004).

If the estimated value of the company's performance is satisfactory, the company should strive to maintain such a level, repeating the measurement process and looking for opportunities for future improvements. If the estimated value of the company's performance is below a satisfactory level, i.e. if, on the basis of measurements as a type of control, deviations from the 
target performance are determined, it is necessary to determine the reasons for the same and propose measures to improve performance.

\section{RESEARCH RESULTS AND DISCUSSION}

In order to demonstrate the applicability of the proposed model of performance management, implementation was performed on one company in the field of food industry. As already mentioned, the basic idea is, first of all, to measure performance (step 1-6) in order to determine the achieved level of performance, and, if necessary, set a strategy to improve performance (step 7), in order to achieve the optimal level of performance.

Step 1. Identification of key performance indicators - as basic performance measures that affect the achieved performance of the company, was performed on the basis of consulting the literature and taking into account the specifics of domestic economic practice. The selected performance measures are classified into five categories, depending on the previously defined key factors: quality, flexibility, employees, efficiency, innovation (Tadic, J., Boljevic, A., 2015).

1. Quality:

- Product characteristics,

- Security and safety of products,

- Price/quality,

- Customer loyalty,

- Customer complaints.

2. Flexibility:

- Product time,

- Time-to-market,

- On-time delivery,

- Validity of shipments.

3. Employees:

- Index of motivation,

- Absence from work,

- Fluctuations of permanent employees,

- Training time per employee,

- Annual investment in training per employee.

4. Efficiency:

- Expenditures size,

- Purchase price,

- Waste,

- Volume of production, 
- Sales price.

5. Innovation:

- R\&D costs of new product

- Time for development and launch of new product,

- New/total products,

- Investments in new technology as a percentage of sales,

- R\&D costs/total costs (\%).

Step 2. Performance measures (key performance indicators) are classified into objective and subjective variables. Objective variables are classified into cost and time dimension:

- Costs: annual investment in training per employee, expenditure size, purchase prices, $\%$ of waste, volume of production, sales prices, R\&D costs of new product, investment in new technology as a percentage of sales, R\&D costs/total costs.

- Time: product time, time-to-market, training time per employee, time for development and launch of new product. .

Step 3. Implementation of a questionnaire in a specific company from the food industry according to the established methodology of model development.

Step 4. After obtaining the necessary data based on the questionnaire, quantification of objective variables into effective and ineffective was performed. Data on effective and ineffective costs are shown in Table 3, and data on effective and ineffective time are shown in Table 4.

Table 3. Objective factor - costs

\begin{tabular}{lcc}
\hline \hline Costs & $\begin{array}{c}\text { Achieved } \\
\text { (in millions of dinars) }\end{array}$ & $\begin{array}{c}\text { Optimal } \\
\text { (in millions of dinars) }\end{array}$ \\
\hline Effective costs (EC) & 5.076 & 5.439 \\
Ineffective costs (IEC) & 1.107 & 744 \\
\hline \hline Source: Author's calculation & & \\
\hline \hline
\end{tabular}

Table 4. Objective factor - time

\begin{tabular}{lcc}
\hline \hline Time & $\begin{array}{c}\text { Achieved } \\
\text { (days) }\end{array}$ & $\begin{array}{c}\text { Optimal } \\
\text { (days) }\end{array}$ \\
\hline Effective time (ET) & 85 & 131 \\
Ineffective time (IET) & 12,2 & 3,3 \\
\hline \hline
\end{tabular}

Source: Author's calculation

Using analytical expression 2, the cost-time efficiency (CTE) of company "X" was calculated: 
0,9079 .

$$
\begin{aligned}
\text { CTE } E_{\text {achieved }}= & {\left[\frac{5.076}{5.076+5.438}\right]+\left[\frac{1.107}{\{(1 / 1.107)+(1 / 744)\}}\right]^{-1} } \\
& +\left[\frac{85}{85+131}\right]+\left[\frac{12,2}{\{(1 / 12,2)+(1 / 3,3)\}}\right]^{-1} \\
& =0,4828+0,000002+0,3935+0,0316=
\end{aligned}
$$

$$
\begin{array}{r}
\text { CTE }_{\text {optimal }}=\left[\frac{5.439}{5.439+5.076}\right]+\left[\frac{744}{\{(1 / 744)+(1 / 1.106)\}}\right]^{-1}+\left[\frac{131}{131+85}\right]+ \\
{\left[\frac{3,3}{\{(1 / 3,3)+(1 / 12,2)\}}\right]^{-1}=0,5172+0,000003+0,6065+0,1167=}
\end{array}
$$

1,2404 .

Using analytical expression 1, the objective variables measurement $(O V M)$ of the company " $\mathrm{X}$ " was performed:

$$
\begin{gathered}
\text { OVM } M_{\text {achieved }}=\left[\frac{0,9079}{0,9079+1,2404}\right]=0,4226, \\
\text { OVM } M_{\text {optimal }}=\left[\frac{1,2404}{1,2404+0,9079}\right]=0,5774 .
\end{gathered}
$$

Step 5. Quantification of subjective variables was performed using an

\begin{tabular}{|c|c|c|c|c|c|c|}
\hline Key factors & Quality & Flexibility & Employee & Efficiency & Innovation & $\overline{\text { Eigen vector }}$ \\
\hline Quality & 1 & 3 & 5 & $1 / 3$ & 4 & 0,269 \\
\hline Flexibility & $1 / 3$ & 1 & 5 & $1 / 3$ & 4 & 0,173 \\
\hline Employee & $1 / 5$ & $1 / 5$ & 1 & $1 / 5$ & $1 / 3$ & 0,045 \\
\hline Efficiency & 3 & 3 & 5 & 1 & 5 & 0,436 \\
\hline Innovation & $1 / 4$ & $1 / 4$ & 3 & $1 / 5$ & 1 & 0,077 \\
\hline$\lambda_{\max }$ & 5,433 & & & & & \\
\hline \multicolumn{7}{|l|}{ Optimal } \\
\hline Key factors & Quality & Flexibility & Employee & Efficiency & Innovation & $\overline{\text { Eigen vector }}$ \\
\hline Quality & 1 & 8 & 3 & $1 / 3$ & 6 & 0,287 \\
\hline Flexibility & $1 / 8$ & 1 & $1 / 6$ & $1 / 8$ & $1 / 3$ & 0,032 \\
\hline Employee & $1 / 3$ & 6 & 1 & $1 / 4$ & 3 & 0,144 \\
\hline Efficiency & 3 & 8 & 4 & 1 & 6 & 0,472 \\
\hline Innovation & $1 / 6$ & 3 & $1 / 3$ & $1 / 6$ & 1 & 0,065 \\
\hline$\lambda_{\max }$ & 5,332 & & & & & \\
\hline
\end{tabular}
analytical hierarchical process. Based on the constructed hierarchical structure of variables, preferences and importance of criteria were determined by developing a set of matrices at each level of research. Table 5 shows the determination of weight values of variables at the first level of research (key factors).

Table 5. Matrix for determining the weights values of key factors (level I) Achieved 
Based on the calculated weight values of key factors, it can be concluded that a particular company attaches the greatest importance to efficiency (0.436), followed by quality (0.269), flexibility (0.173), innovation (0.077) and employees (0.045).

The maximum value of the eigenvector $\left(\lambda_{\max }\right)$ is further used to test the consistency of the model $(C R)$.

$$
\begin{aligned}
& C R_{\text {achieved }}=\frac{0,108}{1,12}=0,097 ; C I=\frac{(5,433-5)}{(5-1)}=0,108 ; \\
& C R_{\text {optimal }}=\frac{0,083}{1,12}=0,074 ; C I=\frac{(5,332-5)}{(5-1)}=0,083 .
\end{aligned}
$$

Considering that the calculated consistency ratio (CR) is less than 0.10 ; the result is accurate enough in both cases and there is no need for corrections in comparisons and repetition of calculations.

The vectors of the second level (components of factors) weights are shown in Table 6, while the vectors of the third level (key performance indicators) weights are shown in Table 7.

Table 6. Matrix for determining the weight values of subjective components of factors (level II)

\begin{tabular}{lcccc}
\hline \hline $\begin{array}{l}\text { Subjective components of } \\
\text { factors }\end{array}$ & & Achieved & Optimal & Eigen vector \\
\hline \multirow{2}{*}{ Food quality } & Achieved & 1 & $1 / 3$ & 0,250 \\
& Optimal & 3 & 1 & 0,750 \\
\hline \multirow{2}{*}{ Customer satisfaction } & Achieved & 1 & $1 / 3$ & 0,250 \\
& Optimal & 3 & 1 & 0,750 \\
\hline \multirow{2}{*}{ On-time delivery } & Achieved & 1 & 0,25 & 0,200 \\
& Optimal & 4 & 1 & 0,800 \\
\multirow{2}{*}{ Employee satisfaction } & Achieved & 1 & $1 / 7$ & 0,125 \\
& Optimal & 7 & 1 & 0,875 \\
\hline \multirow{2}{*}{ R\&D of new product } & Achieved & 1 & $1 / 2$ & 0,333 \\
& Optimal & 2 & 1 & 0,667 \\
\hline \hline
\end{tabular}

Source: Author's calculation 
Table 7. Matrix for determining the weight values of key performance indicators (level III)

\begin{tabular}{|c|c|c|c|c|c|c|c|c|c|c|c|c|}
\hline $\begin{array}{l}\text { Key } \\
\text { performan } \\
\text { ce } \\
\text { indicators }\end{array}$ & $\begin{array}{c}\text { Product } \mathrm{S} \\
\text { characteristic } \\
\mathrm{s}\end{array}$ & $\begin{array}{l}\text { Security and } \\
\text { safety of } \\
\text { products }\end{array}$ & Price/quality & $\begin{array}{l}\text { Customer } \\
\text { loyalty }\end{array}$ & $\begin{array}{l}\text { Customer } \\
\text { complaints }\end{array}$ & $\begin{array}{l}\text { On-time } \\
\text { delivery }\end{array}$ & $\begin{array}{l}\text { Validity of } \\
\text { shipments }\end{array}$ & $\begin{array}{c}\text { Index of } \\
\text { motivation }\end{array}$ & $\begin{array}{l}\text { Absence from } \\
\text { work }\end{array}$ & $\begin{array}{c}\text { Fluctuations } \\
\text { of } \\
\text { permanent } \\
\text { employees }\end{array}$ & $\begin{array}{l}\text { New/total } \\
\text { products }\end{array}$ & Eigen value \\
\hline $\begin{array}{l}\text { Product } \\
\text { characteristic } \\
\mathrm{s}\end{array}$ & 1 & 4 & 0,25 & 0,20 & 4 & 5 & 5 & 6 & 4 & 5 & 4 & 0,152 \\
\hline $\begin{array}{l}\text { Security and } \\
\text { safety of } \\
\text { products }\end{array}$ & 0,25 & 1 & 1 & 0 & 5 & 4 & 3 & 5 & 4 & 6 & 5 & 0,137 \\
\hline Price/quality & 4 & 1 & 1 & 0,33 & 4 & 3 & 4 & 6 & 3 & 4 & 4 & 0,162 \\
\hline $\begin{array}{l}\text { Customer } \\
\text { loyalty }\end{array}$ & 5 & 3 & 3 & 1 & 5 & 5 & 3 & 4 & 4 & 5 & 5 & 0,239 \\
\hline $\begin{array}{l}\text { Customer } \\
\text { complaints }\end{array}$ & 0,25 & 0,20 & 0,25 & 0,20 & 1 & 0,25 & 0,33 & 2 & 3 & 3 & 4 & 0,045 \\
\hline $\begin{array}{l}\text { On-time } \\
\text { delivery }\end{array}$ & 0,20 & 0,25 & 0,33 & 0,20 & 4 & 1 & 5 & 3 & 5 & 5 & 4 & 0,087 \\
\hline $\begin{array}{l}\text { Validity of } \\
\text { shipments }\end{array}$ & 0,20 & 0,33 & 0,25 & 0,33 & 3 & 0,20 & 1 & 3 & 5 & 5 & 4 & 0,066 \\
\hline $\begin{array}{l}\text { Index of } \\
\text { motivation }\end{array}$ & 0,17 & 0,20 & 0,17 & 0,25 & 0,50 & 0,33 & 0,33 & 1 & 4 & 3 & 0,33 & 0,032 \\
\hline $\begin{array}{l}\text { Absence } \\
\text { from } \\
\text { work }\end{array}$ & 0,25 & 0,25 & 0,33 & 0,25 & 0,33 & 0,20 & 0,20 & 0,25 & 1 & 3 & 0,25 & 0,024 \\
\hline $\begin{array}{l}\text { Fluctuations } \\
\text { of } \\
\text { permanent } \\
\text { employees }\end{array}$ & 0,20 & 0,17 & 0,25 & 0,20 & 0,33 & 0,20 & 0,20 & 0,33 & 0,33 & 1 & 0,25 & 0,018 \\
\hline $\begin{array}{l}\text { New/total } \\
\text { products }\end{array}$ & 0,25 & 0,20 & 0,25 & 0,20 & 0,25 & 0,25 & 0,25 & 3 & 4 & 4 & 1 & 0,037 \\
\hline
\end{tabular}

Eigen value of the third level are multiplied by Eigen value of elements from higher, i.e. second level, as shown in Table 8. 
Table 8. Subjective variable measurement

\begin{tabular}{|c|c|c|c|c|c|c|}
\hline \multirow{2}{*}{$\begin{array}{l}\text { Key } \\
\text { performa } \\
\text { nce } \\
\text { indicator } \\
\text { s }\end{array}$} & \multicolumn{3}{|c|}{ Achieved } & \multicolumn{3}{|c|}{ Optimal } \\
\hline & $\begin{array}{l}\text { Eigen value } \\
\text { (level III) }\end{array}$ & $\begin{array}{l}\text { Eigen value } \\
\text { (level II) }\end{array}$ & Total & $\begin{array}{l}\text { Eigen value } \\
\text { (level III) }\end{array}$ & $\begin{array}{l}\text { Eigen value } \\
\text { (level II) }\end{array}$ & Total \\
\hline Product & & & & & & \\
\hline $\begin{array}{l}\text { characteristic } \\
\mathrm{s}\end{array}$ & 0,152 & 0,250 & 0,038 & 0,152 & 0,750 & 0,114 \\
\hline $\begin{array}{l}\text { Security and } \\
\text { safety of } \\
\text { products }\end{array}$ & 0,137 & 0,250 & $\mathbf{0 , 0 3 4}$ & 0,137 & 0,750 & 0,103 \\
\hline Price/quality & 0,162 & 0,250 & 0,041 & 0,162 & 0,750 & 0,122 \\
\hline $\begin{array}{l}\text { Customer } \\
\text { loyalty }\end{array}$ & 0,239 & 0,250 & 0,060 & 0,239 & 0,750 & 0,179 \\
\hline $\begin{array}{l}\text { Customer } \\
\text { complaints }\end{array}$ & 0,045 & 0,250 & 0,011 & 0,045 & 0,750 & $\mathbf{0 , 0 3 4}$ \\
\hline $\begin{array}{l}\text { On-time } \\
\text { delivery }\end{array}$ & 0,087 & 0,200 & 0,017 & 0,087 & 0,800 & 0,070 \\
\hline $\begin{array}{l}\text { Validity of } \\
\text { shipments }\end{array}$ & 0,066 & 0,200 & 0,013 & 0,066 & 0,800 & $\mathbf{0 , 0 5 3}$ \\
\hline $\begin{array}{l}\text { Index of } \\
\text { motivation }\end{array}$ & 0,032 & 0,125 & 0,004 & 0,032 & 0,875 & 0,028 \\
\hline $\begin{array}{l}\text { Absence } \\
\text { from } \\
\text { work }\end{array}$ & 0,024 & 0,125 & 0,003 & 0,024 & 0,875 & 0,021 \\
\hline $\begin{array}{l}\text { Fluctuations } \\
\text { of } \\
\text { permanent } \\
\text { employees }\end{array}$ & 0,018 & 0,125 & 0,002 & 0,018 & 0,875 & 0,016 \\
\hline $\begin{array}{l}\text { New/total } \\
\text { products }\end{array}$ & 0,037 & 0,333 & 0,012 & 0,037 & 0,667 & 0,025 \\
\hline Total & & & 0,236 & & & 0,764 \\
\hline
\end{tabular}

Step 6. Based on the use of quantified data about objective and subjective variables, the system performance measurement of company (SPM) is quantified. To determine the $S P M$, it is necessary to determine the weight of objective and subjective variables. Considering that in a specific company, greater importance is given to subjective variables, a value of 0.4 was taken for $\alpha$. Using analytical expression 6 , the achieved and optimal performance of the company is:

$$
\begin{gathered}
S P M_{\text {achieved }}=(0,4 \times 0,4226)+(0,6 \times 0,236)=0,3106, \\
S P M_{\text {optimal }}=(0,4 \times 0,5774)+(0,6 \times 0,764)=0,6894 .
\end{gathered}
$$


Based on the obtained performance of the company as a system, it can be concluded that the created integrated model of performance management of the company affects the achievement of the optimal level of performance.

Step 7. Taking into account the results of the application of an integrated model of performance management in a particular company, it is possible to develop a set of measures to improve performance, which will be in the function of optimizing the performance of the company.

In the second step of the model, costs and time were identified as key objective variables. The costs are then classified into effective and ineffective, with the realized ineffective costs being far higher than optimal.

- The first optimization measure would be to reduce ineffective costs,

- namely: overhead costs of material, costs of production services (costs of telephone services, maintenance services, leases, advertising and propaganda, etc.), as well as costs of non-production services (costs of security services, services of audits, court costs, representation costs, etc.).

The achieved effective time in a particular company is far less than the optimal time. When we say effective time, we mean productive time, that is, the time used to increase performance. A representative example of productive effective time would be the time of new product development.

- In this regard, another optimization measure would be to increase the effective time, especially the effective productive time for the development of new products and / or new production processes..

Furthermore, in step 5 of the model, the identification of subjective variables was performed. Based on the analysis of achieved and optimal weight values, the following set of measures is proposed:

- raising the level of quality,

- raising the level of efficiency,

- greater focus on employees,

- reducing the level of flexibility and innovation, in the direction of raising the level of the first three measures.

Regarding raising the level of quality in a particular company, it is necessary to increase the quality of food and consumer satisfaction. Improving food quality needs to be done through: improving product characteristics and increasing safety and improving product characteristics. In order to increase consumer satisfaction, it is necessary to take measures to: ensure the required quality at a given price, improve the work of customer complaint services in order to raise the level of customer loyalty etc.

As for raising efficiency in a particular company, it is necessary to increase the level of cost management. In particular, it is necessary to reduce the level of scrap, increase the rationality in the consumption of production 
factors, reduce failures, reduce transport costs and etc. One of the reasons for the lower efficiency of a particular company was the high agreed purchase price from individual agricultural producers at the beginning of the year. Due to negative market trends, the stock price of the finished product was significantly reduced, which also affected the decline in the selling price of final products. At high contracted purchase prices, the decline in the selling price had significant effects on the decline in efficiency.

The final optimization measure is to place a far greater emphasis on employees. The basic measure in that direction is the constant improvement of knowledge and skills of employees through frequent trainings and team building. It is necessary to increase the training time per employee and increase the annual investment in training per employee. In addition, it is necessary to increase employee satisfaction by increasing motivation, reducing absenteeism and reducing the turnover of highly qualified and experienced employees.

\section{CONCLUSION}

The scientific paper presents the application of an integrated performance management model on the example of a specific company in the field of food industry in Serbia. In addition to providing a basis for quantifying performance, it is also developing a methodology for improving performance. A significant contribution of this model is that it combines the qualitative and quantitative dimensions within performance measurement, by operationalizing the relationship between cost, time, and the quality dimension. Objective (quantitative) and subjective (qualitative) measurement variables were converted into consistent indices to measure system performance.

The presented empirical research in this paper has shown the applicability of an integrated performance management model on the example of a specific company in the food industry, and can serve as a support to manufacturing companies. Based on the determined results of measuring objective and subjective variables, and certain achieved and optimal performance of the company as a system, a set of measures to improve performance is proposed, in the function of their optimization. The basic measures to improve performance are reflected in the reduction of ineffective costs and increase the effective time within the objective variables, and raising the level of quality, efficiency, and greater focus on employees within the subjective variables.

Since performance improvement is an ongoing process, companies must strive to achieve optimal cost and profit levels, as well as increase customer 
satisfaction, to ensure the potential for future business. Therefore, the process of measuring and improving performance needs to be frequently implemented and redesigned.

\section{REZIME \\ INTEGRISANI MODEL UPRAVLJANJA PERFORMANSAMA KOMPANIJE PRIMENOM ANALITIČKO HIJERARHIJSKOG PROCESA}

Predloženi model integriše kvantifikaciju performansi (objektivnih i subjektivnih) s jedne strane, i unapređenje performansi, s druge strane. Objektivne varijable su prikazane u vidu troškovne i vremenske dimenzije, dok je za kvantifikovanje subjektivnih varijabli primenjen analitičko hijerarhijski process $(A H P)$. Rezultati istraživanja obezbeđuju uvid u ostvarene i optimalne performance preduzeća, što pruža osnovu za dalja unapređenja performansi.

Ključne reči: integrisani model upravljanja performansama, analitičko hijerarhijski proces, prehrambena industrija.

\section{REFERENCES}

1. Aravindan, Punniyamoorthy. (2002). Justification of Advanced Manufactured Technologies (AMT). The International Journal of Advanced Manufacturing Technology(19), 151-156.

2. Armstrong, M. (2006). Performance Management. London: Kogan Page.

3. Gomes, Yasin \& Lisboa. (2006). Performance measurement practises in manufacturing firms: an empirical investigation. Journal of Manufacturing Technology Management, 17(2), 144-167.

4. Grafton, J., Lillis, M. A., \& Widener, K. S. (2010). The role of performance measurement and evaluation in building organizational capabilities and performance. Accounting, Organizations and Society, 35, 689-706.

5. Hall, M. (2008). The effect of comprehensive performance measurement systems on role clarity, psychological empowerment and managerial performance. Accounting Organizations and Society, 33(2/3), 141-163.

6. Malmi, T., \& Brown, D. (2008). Management control systems as a package - opportunities, challenges and research directions. Management Accounting Research, 14(4), 287-300. 
7. Parthiban, Goh. (2011). An integrated model for performance management of manufacturing units. Benchmarking: An International Journal, 18(2), 261-281.

8. Saaty, T. (1994). How to make a decision: the analytical hierarchy process. Interfaces(24), 19-43.

9. Saaty, T. (2003). Decision making with the AHP: why is the principal eigenvector necessary. European Journal of Opearation Research, 145(1), 85-89.

10. Saaty, T. L. (1980). The analytical hierarchy process. New York: Mc Graw-Hill.

11. Saaty, T.L., Vargas, L.G. (2012). Models, Methods, Concepts and Applications of the Analytic Hierarchy Process (2nd ed.). New York: Springer.

12. Salem, M. (2010). An Application of the Analytic Hierarchy Process to Determine Benchmarking Criteria for Manufacturing Organizations. International Journal of Trade, Economics and Finance, 1(1), 93-102.

13. Spitzer, R. D. (2007). Transforming Performance Measurement: Rethinking the Way We Measure and Drive Organizational Success. New York: Amacom - American Management Association.

14. Tadic, J., Boljevic, A. (2015). Integration of Critical Success Factors in Order to Improve Performance of the Company. Strategic Management, 20(1), 26-33.

15. Tangen, S. (2004). Performance measurement: from philosophy to practice. International Journal of Productivity and Performance Management, 53(8), 726-737.

16. Tonchia, S., Quagini, L. (2010). Performance Measurement: Linking Balanced Scorecard to Business Intelligence . London: Springer.

Ovaj rad je primljen 12.06.2020., a na sastanku redakcije časopisa prihvaćen za štampu 12.08.2020. godine. 